Article

\title{
Preparation and Characterization of Self-Assembled Poly(L-Lactide) on the Surface of $\beta$-Tricalcium Diphosphate(V) for Bone Tissue Theranostics
}

\author{
Jan A. Zienkiewicz ${ }^{1}{ }^{(\mathbb{D}}$, Adam Strzep ${ }^{1}$, Dawid Jedrzkiewicz ${ }^{2}$, Nicole Nowak ${ }^{1}$, \\ Justyna Rewak-Soroczynska ${ }^{1}{ }^{\circledR}$, Adam Watras ${ }^{1}\left({ }^{1}\right.$, Jolanta Ejfler ${ }^{2}$ and Rafal J. Wiglusz $1,3, * \mathbb{C}$ \\ 1 Institute of Low Temperature and Structure Research, Polish Academy of Sciences, Okolna 2 str., \\ 50-422 Wroclaw, Poland; j.zienkiewicz@intibs.pl (J.A.Z.); a.strzep@intibs.pl (A.S.); n.nowak@intibs.pl (N.N.); \\ j.rewak@intibs.pl (J.R.-S.); a.watras@intibs.pl (A.W.) \\ 2 Department of Chemistry, University of Wroclaw, F. Joliot-Curie 14 str., 50-383 Wroclaw, Poland; \\ dawid.jedrzkiewicz@chem.uni.wroc.pl (D.J.); jolanta.ejfler@chem.uni.wroc.pl (J.E.) \\ 3 Centre for Advanced Materials and Smart Structures, Polish Academy of Sciences, Okolna 2 str., \\ 50-950 Wroclaw, Poland \\ * Correspondence: r.wiglusz@intibs.pl; Tel.: +48-071-395-42-74; Fax: +48-071-344-10-29
}

Received: 23 January 2020; Accepted: 11 February 2020; Published: 15 February 2020

\begin{abstract}
This work was aimed to obtain and characterize the well-defined biocomposites based on $\beta$-tricalcium diphosphate $(\mathrm{V})\left(\beta\right.$-TCP) co-doped with $\mathrm{Ce}^{3+}$ and $\mathrm{Pr}^{3+}$ ions modified by poly(L-lactide) (PLLA) with precise tailored chain length and different phosphate to polymer ratio. The composites as well as $\beta$-tricalcium diphosphate $(\mathrm{V})$ were spectroscopically characterized using emission spectroscopy and luminescence kinetics. Morphological and structural properties were studied using X-Ray Diffraction (XRD) and Scanning Electron Microscopy (SEM). The self-assembled poly(L-lactide) in a shape of rose flower has been successfully polymerized on the surface of the $\beta$-tricalcium diphosphate $(\mathrm{V})$ nanocrystals. The studied materials were evaluated in vitro including cytotoxicity (MTT assay) and hemolysis tests. The obtained results suggested that the studied materials may find potential application in tissue engineering.
\end{abstract}

Keywords: $\beta$-tricalcium diphosphate $(\mathrm{V}) ; \mathrm{Ce}^{3+}$ and $\mathrm{Pr}^{3+}$ ions co-doping; poly(L-lactide); theranostics

\section{Introduction}

Theranostics is a field of modern nanomedicine that is based on targeted therapy and medical diagnostic tests. This approach is involved with a dynamic development of chemistry, biology, biotechnology, physics and last, but not least—nanotechnology [1].

In the case of biomaterial, some requirements should be met to be treated as a theranostics agent, but one is obligatorily related to similarity to the original tissue [2]. Moreover, the bone minerals are mostly formed by calcium hydroxyapatites (herein CaHAp) [3]. There are a lot of materials related to the apatite family that could be used in the theranostics applications. Among them is $\beta$-tricalcium diphosphate (herein $\beta$-TCP) that could be a promising agent. This material crystallizes in rhombohedral structure in R3C space group [4]. Furthermore, the CaHAp and $\beta$-TCP are biocompatible, osteoconductive, and bioactive biomaterials. Comparing the $\mathrm{Ca}: \mathrm{P}$ ratios in both materials, hydroxyapatite is more similar to mineralized bone, however resorption time of the $\beta$-TCP-based materials is much shorter due to its much greater solubility in water in $37^{\circ} \mathrm{C}$ [5].

The simplest way to use this material as a bio-imaging agent is a structural modification in order to observe light emission in the range of one of biological optical windows. Our research has showed that $\beta$-TCP doped with $\operatorname{Pr}^{3+}$ ions exhibits an intense emission band near $650 \mathrm{~nm}$. It has been shown 
that luminous efficiency of $\mathrm{Pr}^{3+}$ ions could be further enhanced by $\mathrm{Ce}^{3+}$ co-doping. The literature reports that significant increase of $\mathrm{Pr}^{3+}$ emission via energy transfer from excited $\mathrm{Ce}^{3+}$ ions is observed i.e., in $\mathrm{YAG}\left(\mathrm{Y}_{3} \mathrm{Al}_{5} \mathrm{O}_{12}, \mathrm{Yttrium}\right.$ Aluminum Garnet) crystals [6]. Efficient luminescent properties are needed to precisely monitor temporal stability and spatial migration of introduced material in the bone tissue.

To insert inorganic material into the bone tissue, a carrier agent is needed. In human bone tissue, calcium hydroxyapatite crystals are distributed in the collagen fibrils forming a complex structure. Another way to obtain biomaterial similar to bone tissue is to use bioresorbable polymer. One of the most used ones is polylactide (PLA).

Biodegradable aliphatic polyesters, for example polylactide (PLA), are widely used polymers in a variety of bioapplications such as controlled drug release, gene therapy, regenerative medicine, or implants [7-11]. The most effective and controlled method for PLA synthesis is metal-catalyzed/-initiated ring-opening polymerization (ROP) of lactide [12-14]. Among the wide variety of catalytic systems, the most attractive so far are the single-site initiators based on structural motif L-M-OR, where L is the ancillary ligand, $\mathrm{M}$ is the metal center, and OR is the initiating group [15-23]. Alternative, similarly attractive in the controlled synthesis of PLA are binary catalytic systems based on the homoleptic complexes and external alcohol combination [24-26]. The most widely used system includes commercially available bis(2-ethylhexanoate)tin(II) (Sn(Oct) $)_{2}$ ) catalyst, commonly applied in industry [12]. However, in the context of medical applications, biologically benign complexes $(\mathrm{Zn}, \mathrm{Mg}, \mathrm{Ca})$ are the most searched due to their innocuous nature, ready availability, and their effectiveness for polymerization, both in terms of activity and stereoselectivity. Recently, polymer/inorganic nanocomposite materials have attracted considerable interest because of their excellent properties through synergism of polymer and inorganic nanoparticle (iNPs) components. The key to obtaining suitable in bioaplications polymer/iNPs composites is achieving the fine dispersion of inorganic nanoparticles in the polymer matrix. In terms of variety of synthetic strategies, some of them are more favorable for the formation of polymer/iNPs composites because of the simplicity in materials processing. Among others, it is worth mentioning about binding of polymer chains to iNPs by coating modification, dispersion of iNPs in polymer matrix, and formation of stabilizing polymer shell. PLA is suitable for surface coating of iNPs because of their biocompatibility and versatility while providing a platform for further biological modifications.

The proposed research has been intended to consider the well-characterized theranostics materials for bone damage tissue. Nanocrystalline $\beta$-tricalcium diphosphate ( $\beta$-TCP) (so-called therapeutic part) has been co-doped with $\mathrm{Ce}^{3+}$ and $\mathrm{Pr}^{3+}$ ions (diagnostic part) and coated with poly(L-lactide) (so called a carrier). Moreover, they have been tested in vitro to examine their cytotoxicity using human chondrocyte cell line and mouse osteoblast cell line (MTT assay) and a standard hemolysis test.

\section{Materials and Methods}

\subsection{Materials}

All reactions and operations that required an inert atmosphere of $\mathrm{N}_{2}$ (synthesis of zinc complex $\mathrm{L}_{2} \mathrm{Zn}$ and polymers PLA) were performed using a glovebox (MBraun, Garching, Germany) or standard Schlenk-like apparatus (ILT\&SR PAS, Wroclaw, Poland) and vacuum line techniques. The solvents for synthesis were purified by standard methods before use: n-hexane (VWR, Radnor, PA, USA) distilled from Na; $\mathrm{MeOH}$ (HPLC, VWR, Radnor, PA, USA) distilled from $\mathrm{CaH}_{2} ; \mathrm{CH}_{2} \mathrm{Cl}_{2}$ (99.8\% VWR, Radnor, PA, USA) distilled from $\mathrm{P}_{2} \mathrm{O}_{5}$; deuterated solvents $\left(\mathrm{C}_{6} \mathrm{D}_{6}\right)$, distilled from $\mathrm{NaH}$. Unless otherwise stated, all chemicals were purchased from commercial sources and used without further purification:

Calcium carbonate (99.5\%, Alfa Aesar, Haverhill, MA, USA), ammonium dihydrogen phosphate (99+\%, for analysis, ACROS Organics, Geel, Belgium), cerium(III) nitrate hexahydrate $(99.999 \%$, Alfa Aesar, Haverhill, MA, USA), praseodymium(III, IV) oxide (99.999\%, Sigma-Aldrich, Saint Louis, MO, USA), nitric acid (65\%, Suprapure, Merck, Darmstadt, Germany), citric acid (99\%+, Alfa Aesar, Haverhill, 
MA, USA), ethylene glycol (ultrapure, Avantor Performance Materials Poland S.A., Gliwice, Poland) 2,4-di-tert-buthylphenol (99\%, Sigma-Aldrich, Saint Louis, MO, USA), formaldehyde (37\% solution in $\mathrm{H}_{2} \mathrm{O}$, Sigma-Aldrich, Saint Louis, MO, USA). N-methylcyclohexylamine (99\%, Sigma-Aldrich, Saint Louis, MO, USA), ZnEt 2 (1.0 M solution in $n$-heptane, Sigma-Aldrich, Saint Louis, MO, USA). Proligand $\left[L^{C y}-H\right] N$-[methyl(2-hydroxy-3,5-di-tert-butylphenyl)]-N-methyl- $N$-cyclohexylamine was synthesized according to a literature procedure [24].

\subsection{Synthesis of $\beta$-tricalcium diphosphates ( $\beta$-TCP) Doped with $\mathrm{Pr}^{3+}$ and Co-Doped with Ce ${ }^{3+}$ Ions}

The nanocrystalline $\beta-\mathrm{Ca}_{3}\left(\mathrm{PO}_{4}\right)_{2}$ calcium phosphate co-doped with $\mathrm{Ce}^{3+}$ and $\mathrm{Pr}^{3+}$ ions were prepared by modified Pechini's method, using $18 \mathrm{mmol}$ of $\mathrm{CaCO}_{3}, 12 \mathrm{mmol}$ of $\mathrm{NH}_{4} \mathrm{H}_{2} \mathrm{PO}_{4}, 0.09 \mathrm{mmol}$ of $\mathrm{Ce}\left(\mathrm{NO}_{3}\right)_{3} \cdot 4 \mathrm{H}_{2} \mathrm{O}$, and $0.015 \mathrm{mmol}$ of $\operatorname{Pr}_{6} \mathrm{O}_{11}$. Intentional concentration of the $\mathrm{Ce}^{3+}$ and $\mathrm{Pr}^{3+}$ ions was set to $0.5 \mathrm{~mol} \%$, in replacement of overall molar content of $\mathrm{Ca}^{2+}$ ions.

In this method, stoichiometric amounts of $\mathrm{CaCO}_{3}$ and $\mathrm{Pr}_{6} \mathrm{O}_{11}$ were weighed and digested in excess of $\mathrm{HNO}_{3}$ (Suprapure, Merck) in order to transform them into nitrates. Subsequently, cerium nitrate was dissolved in deionized water together with calcium and praseodymium (III) nitrates. Afterwards, the excess (12,5-fold relative to the total amount of cations) of citric acid as well as ethylene glycol were added under constant stirring at $60^{\circ} \mathrm{C}$, resulting in a viscous mixture. Finally, a suitable amount of ammonium hydrogen phosphate was added. The temperature was raised up to $120^{\circ} \mathrm{C}$. The heating was continued until a white voluminous foam was obtained. The mixture was further dried for 3 days at $90{ }^{\circ} \mathrm{C}$. Afterwards, the resin thus obtained was calcinated in a temperature of $900{ }^{\circ} \mathrm{C}$. As a result, a white powder $(\beta-\mathrm{TCP})$ was obtained.

\subsection{Synthesis of poly(L-lactide) (PLLA)}

Synthesis of PLLA was divided into two parts. At first, the initiator was synthetized. Afterwards, ring opening polymerization of L-lactide was carried out. Oligomeric chains based on L-lactide with methyl ending group were prepared in ring opening polymerization (ROP) reaction. Homoleptic zinc aminophenolate complex type $\mathrm{ZnL}_{2}(L=$ $\mathrm{N}$-methyl-(2-hydroxy-3,5-di-tert-buthylphenyl)]-N-cyclohexylamine) as initiator was used. High efficiency of this catalyst was described in the literature [24-26].

\subsubsection{Synthesis of Initiator}

$\left[\left(\mathrm{L}^{\mathrm{Cy}}\right)_{2} \mathrm{Zn}\right]$ was synthesized following a modified procedure of our previous report [25].

To a stirred solution of $0.66 \mathrm{~g}(2.00 \mathrm{mmol})$ of proligand $\mathrm{L}^{\mathrm{Cy}}-\mathrm{H}$ in $n$-hexane $(20 \mathrm{~mL}), 1.00 \mathrm{~mL}$ $(1.00 \mathrm{mmol})$ of $\mathrm{ZnEt}_{2}$ (1.0 M solution in $n$-heptane) was added dropwise at ambient temperature. Next, the solution was stirred for $12 \mathrm{~h}$ until a crude product precipitated. The white powder of $\left[\left(\mathrm{L}^{\mathrm{Cy}}\right)_{2} \mathrm{Zn}\right]$ was collected by filtration, washed with cold n-hexane, and dried in vacuo. Yield: $92 \%(0.67 \mathrm{~g}, 0.92 \mathrm{mmol})$. Anal. Calcd (Found) for $\mathrm{C}_{44} \mathrm{H}_{72} \mathrm{~N}_{2} \mathrm{O}_{2} \mathrm{Zn}$ (726.41): C 72.75 (72.83), $\mathrm{H} 9.99$ (9.86), N 1.96 (1.85)\%. ${ }^{1} \mathrm{H}$ NMR for major form $\left(500 \mathrm{MHz}, \mathrm{C}_{6} \mathrm{D}_{6}, 298 \mathrm{~K}\right): \delta=7.72\left(2 \mathrm{H}, \mathrm{d}, \mathrm{ArH}, J_{\mathrm{HH}}=2.6 \mathrm{~Hz}\right), 7.09\left(2 \mathrm{H}, \mathrm{d}, \mathrm{ArH}, J_{\mathrm{HH}}=\right.$ $2.6 \mathrm{~Hz}), 4.16\left(2 \mathrm{H}, \mathrm{d}, \mathrm{N}-\mathrm{CH}_{2}-\mathrm{Ar}, J_{\mathrm{HH}}=12.1 \mathrm{~Hz}\right), 3.47\left(2 \mathrm{H}, \mathrm{d}, \mathrm{N}-\mathrm{CH}_{2}-\mathrm{Ar}, J_{\mathrm{HH}}=12.1 \mathrm{~Hz}\right), 3.20(2 \mathrm{H}, \mathrm{m}$, $\left.\mathrm{C}_{6} \mathrm{H}_{11}\right), 2.48\left(6 \mathrm{H}, \mathrm{s}, \mathrm{NCH}_{3}\right), 1.74\left(18 \mathrm{H}, \mathrm{s}, \mathrm{C}\left(\mathrm{CH}_{3}\right)_{3}\right), 1.66\left(10 \mathrm{H}, \mathrm{m}, \mathrm{C}_{6} \mathrm{H}_{11}\right), 1.59\left(18 \mathrm{H}, \mathrm{s}, \mathrm{C}\left(\mathrm{CH}_{3}\right)_{3}\right), 1.05$ $\left(10 \mathrm{H}, \mathrm{m}, \mathrm{C}_{6} \mathrm{H}_{11}\right) \cdot{ }^{13} \mathrm{C} \mathrm{NMR}\left(500 \mathrm{MHz}, \mathrm{C}_{6} \mathrm{D}_{6}, 298 \mathrm{~K}\right) \delta=164.3,138.4,135.5,125.9,124.4,120.5(12 \mathrm{C}, \mathrm{Ar})$, $\left.65.3\left(\mathrm{~N}-\mathrm{CH}_{2}-\mathrm{Ar}\right), 61.9\left(2 \mathrm{C}, \mathrm{C}_{6} \mathrm{H}_{11}\right), 36.8\left(\mathrm{C}\left(\mathrm{CH}_{3}\right)_{3}\right), 35.5\left(\mathrm{C}\left(\mathrm{CH}_{3}\right)_{3}\right), 33.8\left(\mathrm{NCH}_{3}\right), 32.3\left(\mathrm{C}(\mathrm{CH})_{3}\right)_{3}\right), 30.2$ $\left.\left(\mathrm{C}(\mathrm{CH})_{3}\right)_{3}\right), 26.9,26.1,24.4\left(10 \mathrm{C}, \mathrm{C}_{6} \mathrm{H}_{11}\right)$.

\subsubsection{Representative Procedure for Solution Polymerization}

ROP polymerization of L-Lactide while using binary catalytic system $\left[\left(L^{C y}\right)_{2} \mathrm{Zn}\right] / \mathrm{MeOH}$.

The solution of zinc complex $\left[\left(L^{C y}\right)_{2} \mathrm{Zn}\right]$ in $\mathrm{CH}_{2} \mathrm{Cl}_{2}(15 \mathrm{~mL})$ was placed in a Schlenk flask, and $\mathrm{MeOH}$ and L-lactide in molar ratio $\left[\left(L^{C y}\right)_{2} \mathrm{Zn}\right] / \mathrm{MeOH} / \mathrm{L}$-Lactide $1 / 1 / 15$ was added. The obtained solution was stirred for $5 \mathrm{~h}$. At certain time intervals, about $1 \mathrm{~mL}$ aliquots were removed, precipitated 
with hexanes, and dried in vacuo. The obtained precipitates were dissolved in $\mathrm{C}_{6} \mathrm{D}_{6}$ and used for the conversion monitoring, which was determined by ${ }^{1} \mathrm{H}$ NMR. After the reaction was completed, an excess of hexanes was added to the reaction mixture. The obtained crude polymer was next filtered off and dried in vacuo. The resulting powder was dissolved in dichloromethane and the PLA was precipitated with excess of cold hexanes. The PLA was collected by filtration, washed with hexanes, and dried in vacuo. The reaction mixture was prepared in glovebox, and the next subsequent operations for the isolation of pure PLLA were performed by using standard Schlenk apparatus and vacuum line techniques.

\subsection{Representative Procedure for Preparation of $\beta$-TCP@PLLA Composites}

TCP@PLA composites were obtained by using precipitation method.

To the sample of polymer, PLLA (50 mg) dissolved in $1 \mathrm{~mL}$ of $\mathrm{CH}_{2} \mathrm{Cl}_{2}$ nanocrystalline $\beta$-TCP $(5 \mathrm{mg})$ was added and the mixture was stirred at room temperature for $0.5 \mathrm{~h}$. The $\beta$-TCP@PLLA composites were precipitated with an excess of hexanes $(50 \mathrm{~mL})$, which was added dropwise over $10 \mathrm{~min}$. Next the hexane was removed by decantation and composite material was purified by washing in hexane $(3 \times 50 \mathrm{~mL})$ and isolated by drying the precipitate afterwards under reduced pressure during $72 \mathrm{~h}$ in the temperature $60^{\circ} \mathrm{C}$.

\subsection{Physicochemical Characterization}

${ }^{1} \mathrm{H},{ }^{13} \mathrm{C}$ NMR spectra were obtained using Bruker Avance $500 \mathrm{MHz}$ spectrometer (Bruker, Billerica, MA, USA). The chemical shifts are given in ppm and referenced to the residual protons in the deuterated solvents. Microanalyses were conducted with an Elementar CHNS Vario EL III analyzer (Elementar, Langenselbold, Germany).

X-Ray Powder Diffraction (XRD) studies were carried out using PANalytical X'Pert Pro diffractometer (Malvern Panalytical Ltd, Malvern, UK) equipped with Ni-filtered $\mathrm{Cu} \mathrm{K} \alpha$ radiation $(V=40 \mathrm{kV}, I=30 \mathrm{~mA}, \lambda=1.5406 \AA$ ). The XRD patterns were collected during $3 \mathrm{~h}$ in the $2 \theta$ range of $10-60^{\circ}$.

The microstructure investigations and elemental analysis were carried out using a scanning electron microscope FEI Nova NanoSEM 230 (FEI Company, Hillsboro, OR, USA) equipped with EDS spectrometer (EDAX PegasusXM4) (EDAX Inc., Mahwah, NJ, USA). TCP sample was attached to the measuring table using graphite tape and imaged at an accelerated voltage $10 \mathrm{kV}$. In order to eliminate the effect of collecting charge on the surface of material, PLLA and composite samples were imaged at an accelerated voltage $5 \mathrm{kV}$ and $10 \mathrm{kV}$.

High-resolution emission spectra and luminescence kinetics curves were recorded using excitation wavelength $445 \mathrm{~nm}$. Opolette Nd:YAG Laser-OPO system (Opotek INC, CA, USA) was used as an excitation source. Emission spectra were recorded with use of DongWooOptron d750 monochromator (DongWoo Optron, Maesan-ri, South Korea). Light was collected by Hamamatsu R928 photomultiplier (Hamamatsu Photonics K.K., Hamamatsu, Japan). Signal from the photomultiplier was analyzed in parallel by SR250 Gated Integrator (Stanford Research System, Sunnyvale, CA, USA) for integration of signal and a Tektronix TDS 3050 digital oscilloscope (luminescence kinetics) (Tektronix Inc., Beaverton, OR, USA).

\subsection{Evaluation of Biological Properties}

Potential non cytotoxic properties of obtained materials were evaluated via MTT assay by using human chondrocyte cell line (TC28A2) and mouse osteoblast (7F2) cell lines. Hemolysis assay by using ram blood cells was performed to estimate possible hemolytic activity of our composites.

\subsubsection{Human Chondrocytes Cell Line}

TC28A2 human chondrocyte cell line was maintained in high glucose Dulbecco's Modyfied Eagle Medium (DMEM) with L-glutamine (Biowest, Nuaillé, France) and supplemented with 10\% 
Fetal Bovine Serum (FBS) South America Heat Inactivated (Biowest, Nuaillé, France), 200 U/mL penicillin, and $200 \mu \mathrm{g} / \mathrm{mL}$ streptomycin. Mouse osteoblast cell line (7F2) was cultured in Minimum Essential Medium Eagle-alpha modification ( $\alpha$-MEM) without nucleosides (Biowest, Nuaillé, France). To obtain a full cultured medium, $\alpha$-MEM was supplemented with $10 \%$ FBS and $2 \mathrm{mM}$ stable glutamine (Biowest, Nuaillé, France). TC28A2 and 7F2 cell lines were incubated in standard conditions at $37^{\circ} \mathrm{C}$ in humidified atmosphere of $5 \% \mathrm{CO}_{2}$ and $95 \%$ air. Passive cells were used three times in the experiments.

\subsubsection{Influence of Obtained Composites on Chondrocytes Proliferation Rate}

Proliferation capacity of human chondrocytes and mouse osteoblast were evaluated via performing MTT cytotoxicity assay Tc28A2 and 7F2 cells were seeded at density 10,000 cells per well in 96-well plates and allowed to attached and grow for $24 \mathrm{~h}$. Then, cells were washed with sterile PBS (Biowest, Nuaillé, France), and fresh medium and adequate concentration of tested compounds, $(50 \mu \mathrm{g} / \mathrm{mL}$ and $100 \mu \mathrm{g} / \mathrm{mL}$ of $\beta-\mathrm{Ca}_{3}\left(\mathrm{PO}_{4}\right)_{2}$, PLLA and composite) was added. MTT (BioReagent, $>97.5 \%$, Sigma-Aldrich, Saint Louis, MO, USA) assay was performed $24 \mathrm{~h}$ after cells treatment. Treatment medium was removed and sterile PBS containing $0.5 \mathrm{mg} / \mathrm{mL}$ MTT (tiazol blue tertazolium) was added, and cells were incubated $3 \mathrm{~h}$ at $37^{\circ} \mathrm{C}$. After incubation, medium containing MTT was removed without washing, and formed formazan crystals were dissolved in DMSO (99.5\%, Sigma-Aldrich, Saint Louis, MO, USA). Absorbance was read with a Varioskan LUX plate reader (ThermoFisher Scientific, Waltham, MA, USA) at $560 \mathrm{~nm}$ with background reference at $670 \mathrm{~nm}$. The experiment was performed three times. Percentage of cell viability was calculated using the following formula:

$$
\text { Cells viability }=\frac{\text { sample absorbance }}{\text { control absorbance }} \times 100 \% \text {. }
$$

As a reference control (100\% of cells viability), samples of non-treated cells were used in both cell lines.

\subsubsection{Hemolysis Assay}

Hemolysis assay was performed according to the protocol described elsewhere with the slight modification [27]. Ram blood (ProAnimali, Wroclaw, Poland) was centrifuged (3000 RPM, 10 min) in order to obtain erythrocyte fraction, which was washed with PBS (phosphate-buffered saline, $\mathrm{pH} 7.4$ ) and mixed with fresh PBS (1:1 v/v). $\beta-\mathrm{Ca}_{3}\left(\mathrm{PO}_{4}\right)_{2} ; \mathrm{PLLA}$ and the $\beta-\mathrm{Ca}_{3}\left(\mathrm{PO}_{4}\right)_{2} / \mathrm{PLLA}(1: 10)$ composite were mixed with erythrocytes at final concentration of 50 and $100 \mu \mathrm{g} / \mathrm{mL}$ and incubated in $37^{\circ} \mathrm{C}$ for $2 \mathrm{~h}$. Then, samples were centrifuged in order to obtain supernatant (5000 RPM, $5 \mathrm{~min}$ ) and the optical density was measured at $540 \mathrm{~nm}$ with a Varioskan LUX plate reader (ThermoFisher Scientific, Waltham, MA, USA). As a reference control (100\% of hemolysis), the $1 \%$ solution of SDS (sodium dodecyl sulfate) was used and as negative control the solution of PBS (phosphate-buffered saline) was applied. Obtained results were compared with the absorbance of SDS sample and shown as a percentage of hemolysis and the hemolysis percentage was calculated as using following formula:

$$
\text { Hemolysis }=\frac{\text { sample absorbance }- \text { negative control absorbance }}{\text { positive control absorbance }- \text { negative control absorbance }} \times 100
$$

\section{Results and Discussion}

\subsection{Structural Properties}

\subsection{1. $\beta$-tricalcium diphosphate $(\beta-\mathrm{TCP})$}

Structure and phase purity were checked with the powder XRD technique and were compared with the reference standard of the tetragonal $\beta-\mathrm{Ca}_{3}\left(\mathrm{PO}_{4}\right)_{2}$ lattice ascribed to the $R-3 c$ space group. Diffractograms of $\beta$-TCP co-doped with $\mathrm{Ce}^{3+}$ and $\mathrm{Pr}^{3+}$ and TCP@PLLA composite as well as the 
theoretical XRD pattern of $\beta-\mathrm{Ca}_{3}\left(\mathrm{PO}_{4}\right)_{2}$ (ICSD 97500) and the diffractogram of pure PLLA are shown in Figure 1.

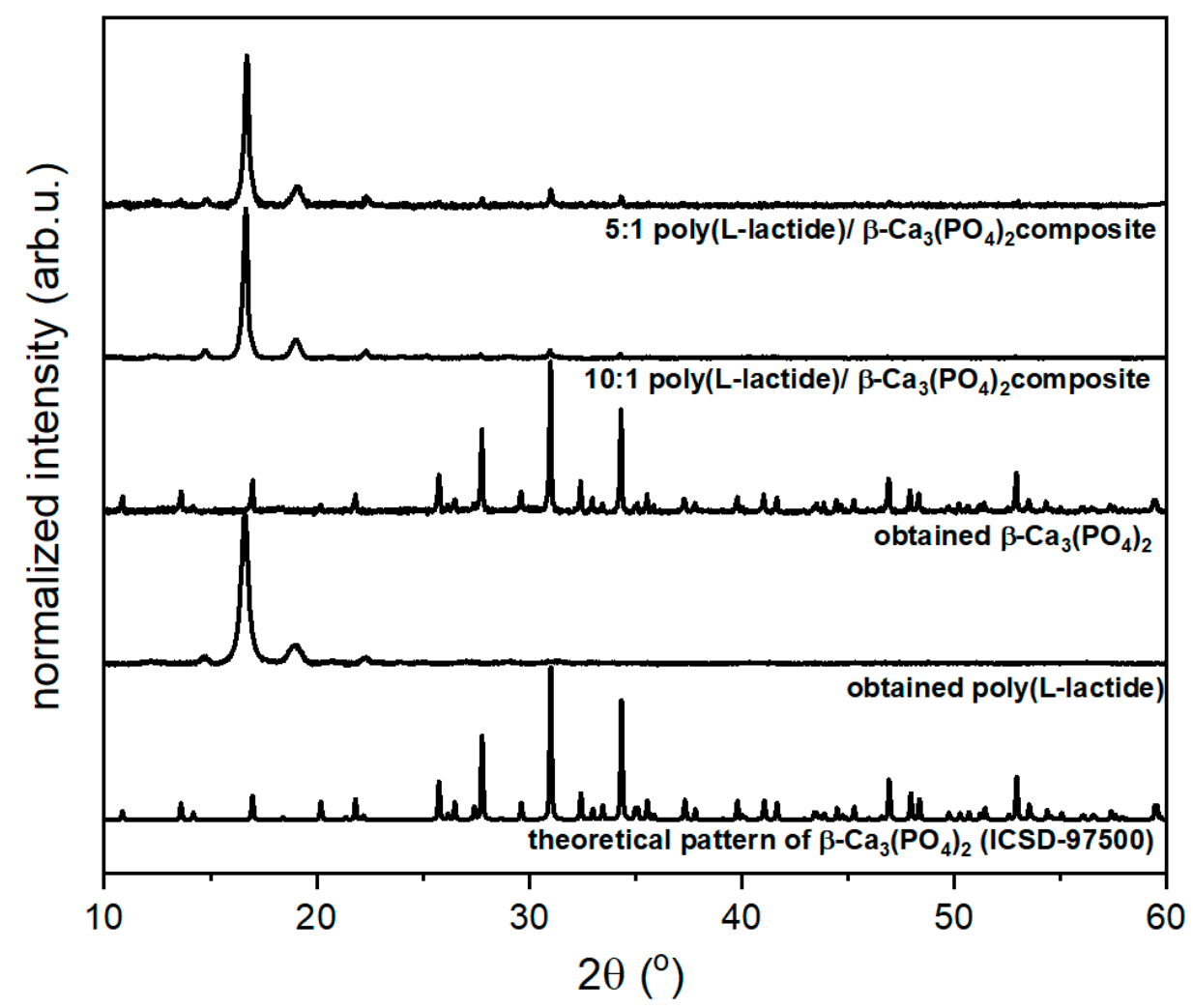

Figure 1. X-ray diffraction patters of poly(L-lactide) (PLLA), $\beta-\mathrm{Ca}_{3}\left(\mathrm{PO}_{4}\right)_{2}(\beta-\mathrm{TCP})$ co-doped with $\mathrm{Ce}^{3+}$ and $\mathrm{Pr}^{3+}$ ions and PLLA with $\beta-\mathrm{Ca}_{3}\left(\mathrm{PO}_{4}\right)_{2}$ composite compared to theoretical pattern of $\beta-\mathrm{Ca}_{3}\left(\mathrm{PO}_{4}\right)_{2}$ (ICSD-97500).

$\beta$-TCP crystallized in rhombohedral structure, in the space group $R 3 c$. Due to Shannon, $\mathrm{Ca}^{2+}$, $\mathrm{Ce}^{3+}$, and $\operatorname{Pr}^{3+}$ effective ionic radii were $1.00 \AA, 1.01 \AA$, and $0.99 \AA$, respectively [28]. Due to similar ionic radiilanthanide, ions substituted $\mathrm{Ca}^{2+}$ sites in the $\beta$-TCP matrix lattice.

\subsubsection{Poly(L-lactide) (PLLA)}

The activity and effectiveness of binary catalytic system $\left[\left(L^{C y}\right)_{2} \mathrm{Zn}\right] / \mathrm{MeOH}$ to synthesis of PLLA in living ROP of lactides from high and ultra-low molecular weight was recently published. That catalytic system is well suited especially for the synthesis of precisely defined oligolactides in comparison with the commercial $\mathrm{Sn}(\mathrm{Oct})_{2}$, which is not as selective as $\left[\left(L^{\mathrm{Cy}}\right)_{2} \mathrm{Zn}\right] / \mathrm{ROH}$. Additionally, the most popular $\mathrm{Sn}(\mathrm{Oct})_{2}$ used for the synthesis of low molecular PLLA produces the oligolactides with the fraction of alkyl-(S,S)-O-lactyllactate. Therefore, the precisely defined polymer matrix containing planned 15 lactide units has been obtained by using $\left[\left(L^{C y}\right)_{2} \mathrm{Zn}\right] / \mathrm{MeOH}$ catalytic system. Under selected molar ratio of ROP components $\left[\left(L^{C y}\right)_{2} \mathrm{Zn}\right] / \mathrm{MeOH} / \mathrm{L}-\mathrm{LA}=1 / 1 / 15$, the oligomer 15-PLLA-Me were obtained (Figure 2).

The end groups and the number of lactide units were detected by using NMR spectroscopy. The ${ }^{1} \mathrm{H}$ NMR spectra for 15-PLLA-Me oligomer showed expected resonances for both chains end, methyl ester and hydroxyl groups, and oligolactide backbone chain (Figure 3). The most intense signals $A_{3}$ and $B_{3}$ corresponded to methine and methyl groups of repetitive central open lactide units. The adequate resonances of open lactide units close to end groups were denoted as $A_{1-2} B_{1-2}$ (a couple of signals coming from neighboring mer to hydroxy end) and $\mathrm{A}_{4-5} \mathrm{~B}_{4-5}$ (the first open lactide molecule close to ester chain end) (see Figure 2). 
<smiles>C[C@@H]1OC(=O)[C@H](C)OC1=O</smiles><smiles></smiles>

Figure 2. Synthesis of 15-PLLA-Me oligomer.

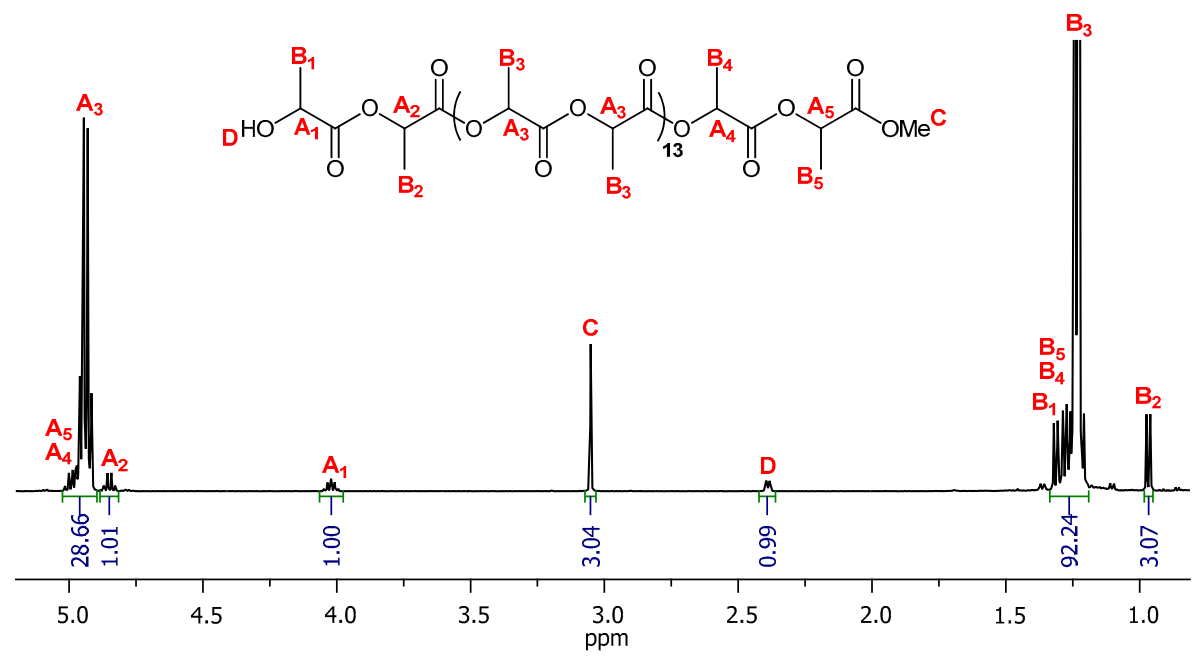

Figure 3. ${ }^{1} \mathrm{H}$ NMR spectrum of 15-PLLA-Me oligomer $\left(C_{6} D_{6}\right)$.

\subsection{Morfological Properties}

SEM images of uncoated $\beta$-TCP (A) and poly(L-lactide) (B) compared to $\beta$-TCP coated with PLLA in two $\beta$-TCP:PLLA ratios: 1:10 (C) and 1:20 (D) are presented in Figure 4.
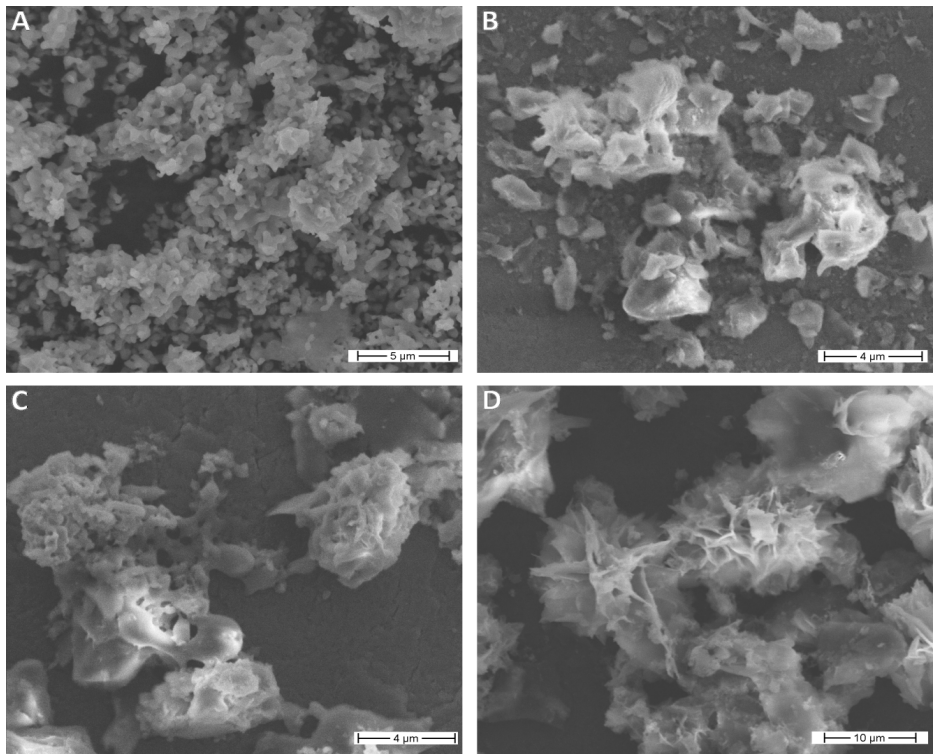

Figure 4. SEM images of (A) $\beta$-TCPco-doped with $\mathrm{Ce}^{3+}$ and $\mathrm{Pr}^{3+}$ ions, (B) PLLA, (C) PLLA with $\beta$-TCP composite with phosphate:polymer 1:10 ratio, and (D) PLLA with $\beta$-TCP composite with phosphate:polymer 1:20 ratio. 
The surface of the sample coated with 1:20 ratio (D) clearly showed new morphology with the shape of rose flower, while surfaces of pure PLLA (B) and the sample coated with 1:10 ratio (C) were much smoother.

\subsection{Spectroscopic Properties}

\subsubsection{Emission Spectra}

Emission spectra were measured in the range of wavelength from $500 \mathrm{~nm}$ to $700 \mathrm{~nm}$ after excitation with $445 \mathrm{~nm}$. Emission spectra of $\beta$-TCP:0.5\%Ce; $0.5 \% \operatorname{Pr}$ sintered at $900{ }^{\circ} \mathrm{C}$ for $3 \mathrm{~h}$, pure and coated with poly(L-lactide) upon excitation at $445 \mathrm{~nm}$, are presented in Figure 5.

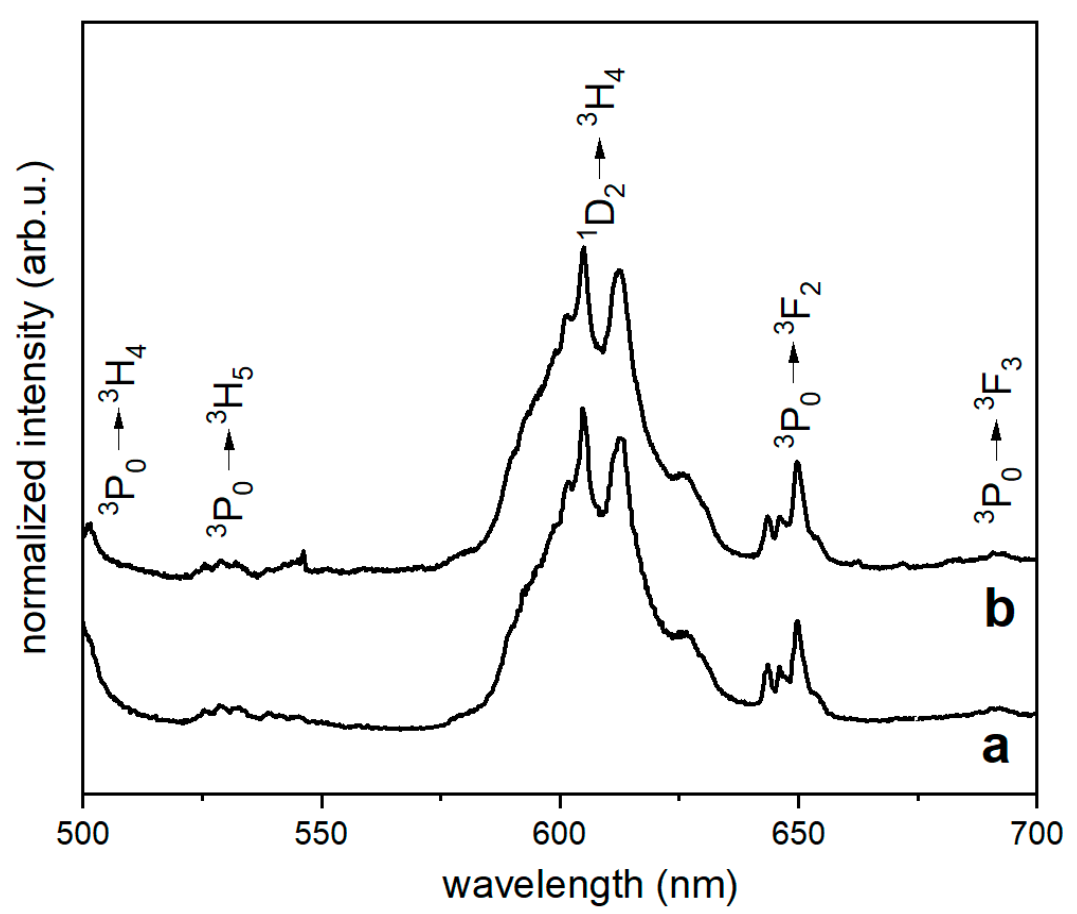

Figure 5. Emission spectra of PLLA with $\beta$-TCP co-doped with $\mathrm{Ce}^{3+}$ and $\mathrm{Pr}^{3+}$ ions (a) and PLLA with $\beta$-TCP composite with phosphate:polymer 1:20 ratio $(\mathbf{b})$. Spectra were recorded after excitation with $445 \mathrm{~nm}$.

The $\mathrm{Ce}^{3+}$ and $\mathrm{Pr}^{3+}$-co-doped tricalcium $\beta$-diphosphate showed prominent ${ }^{1} \mathrm{D}_{2} \rightarrow{ }^{3} \mathrm{H}_{4}$ and ${ }^{3} \mathrm{P}_{0} \rightarrow$ ${ }^{3} \mathrm{~F}_{2}$ transitions. The ${ }^{3} \mathrm{P}_{0} \rightarrow{ }^{3} \mathrm{~F}_{2}$ transition was less intense than the ${ }^{1} \mathrm{D}_{2} \rightarrow{ }^{3} \mathrm{H}_{4}$, but it was observed near $650 \mathrm{~nm}$-in the range of first optical window for biological tissues. Spectrum of pure $\beta$-TCP co-doped with $\mathrm{Ce}^{3+}$ and $\mathrm{Pr}^{3+}$ ions was identical to the spectrum of coated with PLLA. This means that the presence of the coating layer did not change luminescent properties of $\beta$-TCP core. Furthermore, resemblance of both spectra suggests that $\mathrm{Pr}^{3+}$ ions remained in phosphate structure and did not diffuse to polymer body.

\subsubsection{Luminescence Kinetics}

Luminescence kinetics curves were recorded after excitation with $445 \mathrm{~nm}$. Decays from the ${ }^{1} D_{2}$ and ${ }^{3} P_{0}$ state were observed at subsequently 605 and $650 \mathrm{~nm}$.

Lifetimes of the ${ }^{1} D_{2}$ and ${ }^{3} P_{0}$ states of $\operatorname{Pr}^{3+}$ ions were not mono-exponential. Average lifetimes of all materials were calculated from the equation (Table 1 ):

$$
\tau_{a v g}=\frac{\int I(t) t d t}{\int I(t) d t}
$$


where: $I$ —intensity; $t$ —-time; $\tau_{\text {avg }}$ —average lifetime.

Table 1. Calculated lifetimes of $\beta$-TCP co-doped with $\mathrm{Ce}^{3+}$ and $\mathrm{Pr}^{3+}$ ions PLLA with $\beta-\mathrm{Ca}_{3}\left(\mathrm{PO}_{4}\right)_{2}$ composite with phosphate:polymer 1:10 ratio and PLLA with $\beta$-TCP composite with phosphate:polymer 1:20 ratio. Delays from the state ${ }^{3} \mathrm{P}_{0}$ were observed at $650 \mathrm{~nm}$ and delays from the state ${ }^{1} \mathrm{D}_{2}$ were observed at $605 \mathrm{~nm}$.

\begin{tabular}{cccc}
\hline Materials & State & Observed Wavelength $[\mathrm{nm}]$ & Lifetime $[\mu \mathrm{s}]\left(\tau_{\text {avg }}\right)$ \\
\hline \multirow{3}{*}{-TCP:0.5\%Ce/0.5\% $\mathrm{Pr}, 900{ }^{\circ} \mathrm{C}$} & ${ }^{3} P_{0}$ & 650 & 1.31 \\
& ${ }^{1} D_{2}$ & 605 & 84.39 \\
$\beta$-TCP/PLLA composite $1: 20$ & ${ }^{3} P_{0}$ & 650 & 1.28 \\
& ${ }^{1} D_{2}$ & 605 & 84.50 \\
$\beta$-TCP/PLLA composite $1: 10$ & ${ }^{3} P_{0}$ & 650 & 1.34 \\
& ${ }^{1} D_{2}$ & 605 & 77.28 \\
\hline
\end{tabular}

${ }^{1} \mathrm{D}_{2}$ lifetimes in pure TCP and $10 \%$ composite with PLLA were the same, but in the $5 \%$ composite, they were a little bit shorter; however, differences between samples were too scarce to consider them as a significant influence of polymer coating. Decay curves observed at $650 \mathrm{~nm}$ and $605 \mathrm{~nm}$ are presented in Figure 6.
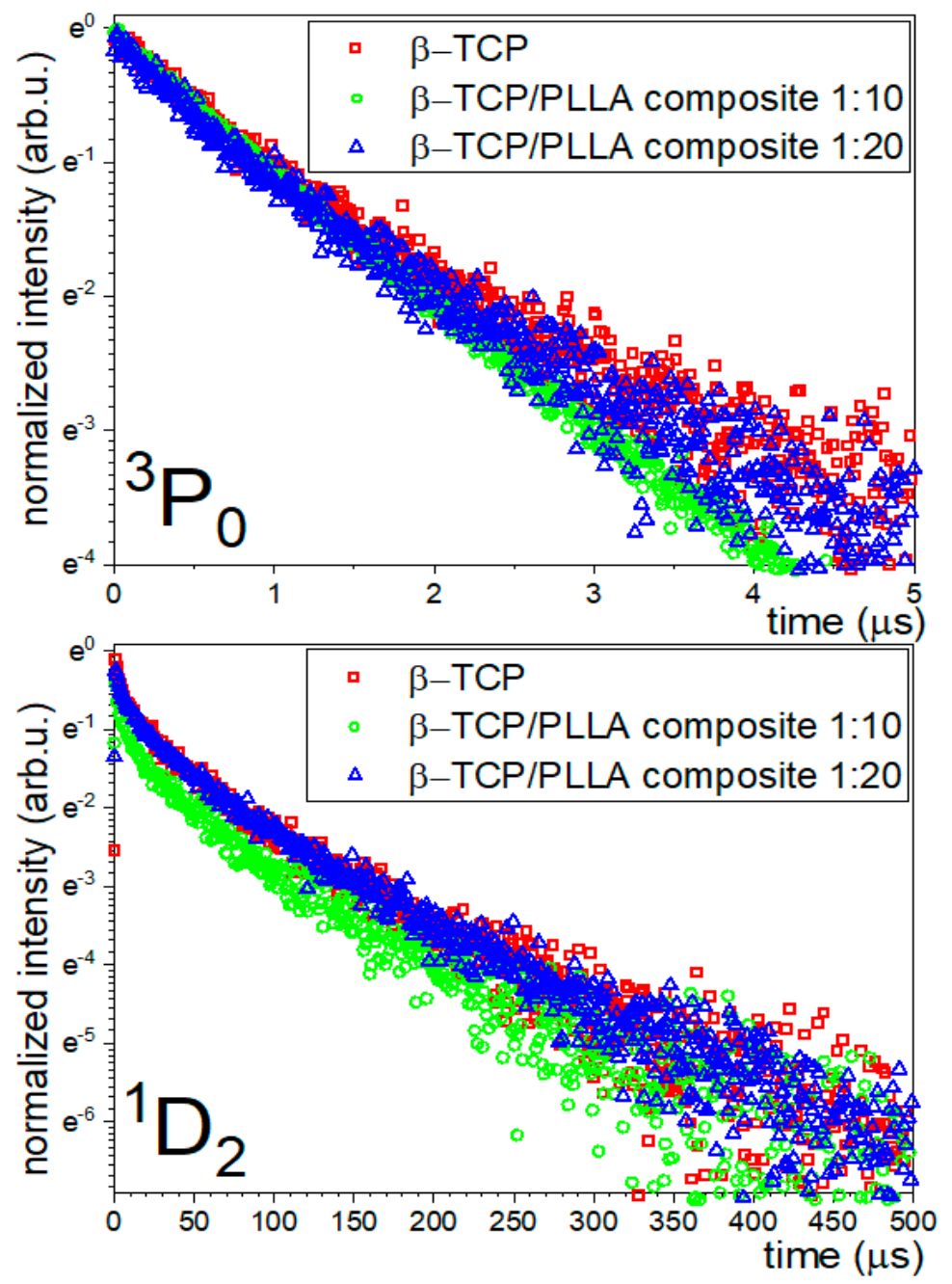

Figure 6. Luminescence kinetics curves of $\beta$-TCP co-doped with $\mathrm{Ce}^{3+}$ and $\mathrm{Pr}^{3+}$ ions PLLA with $\beta$-TCP composite with phosphate: polymer 1:10 ratio and PLLA with $\beta$-TCP composite with phosphate: polymer 1:20 ratio, recorded at $650 \mathrm{~nm}\left({ }^{3} P_{0}\right)$ and recorded at $605 \mathrm{~nm}\left({ }^{1} D_{2}\right)$. 
Decay time of the luminescence from the state ${ }^{3} P_{0}$ observed at $650 \mathrm{~nm}$ was about $1 \mu \mathrm{s}$ in each studied case, which was much longer than the luminescence lifetime of emission exhibited by organic molecules from biological tissue [29,30]. This feature could be used to easily discern whether observed luminescence comes from tissue-related molecules or artificially introduced $\beta$-TCP. Time dependency and spectral shape of luminesce from introduced material could be used to precisely monitor temporal stability and spatial migration of $\beta$-TCP in the bone tissue. Location and stability monitoring are needed to fulfil diagnostic part of $\beta$-TCP/PLLA composite possible theranostics application.

\subsection{Biological Features}

\subsubsection{Cytotoxicity Assay}

Our results clearly showed that some of the tested materials increased cell proliferation rate in both concentrations $50 \mu \mathrm{g} / \mathrm{mL}$ and $100 \mu \mathrm{g} / \mathrm{mL}$ in the TC28A2 cell line, which may indicate enhancement of metabolic activity of treated cells. PLLA seems to be degraded in an extracellular environment to L-lactide and then may be transported via MTCs (monocarboxylate transporters) and used by chondrocytes as an energetic fuel [31]. Additionally, chondrocytes proliferation rate was higher than $50 \%$ even in the $100 \mu \mathrm{g} / \mathrm{mL}$ concentration of all tested composites. Obtained results were collected in Figure 7. Intriguingly, in comparison with chondrocytes, viability of $7 \mathrm{f} 2$ cells treated with PLLA maintain edat $74 \%$ in concentration $50 \mu \mathrm{g} / \mathrm{mL}$ and seemed to gradually decrease in higher concentrations. The lower proliferation rate of 7F2 cells may be explained by increased lactate production in osteoblasts, which was caused by the aerobic glycolysis even in the presence of oxygen. This type of metabolism was similar to the Warburg effect, the major hallmark of cancer. It transpired that specific metabolic needs of osteoblasts demanded this particular type of metabolism. Elevated concentrations of lactic acid may additionally acidify extracellular environment, thus osteoblast cells do not use PLLA as an energy fuel like chondrocytes [32]. When compared to other compounds, the viability of mouse osteoblasts maintains around 75\% when treated with $\beta$-TCP and the composite at a concentration of $50 \mu \mathrm{g} / \mathrm{mL}$ and around $60 \%$ at a concentration of $100 \mu \mathrm{g} / \mathrm{mL}$. This may indicate that the osteoblast cell line is more sensitive to alterations in extracellular environment. However, what is the most important is that proliferation of TC28A2 and 7F2 cell lines was maintained above 50\% in each sample and both concentrations.

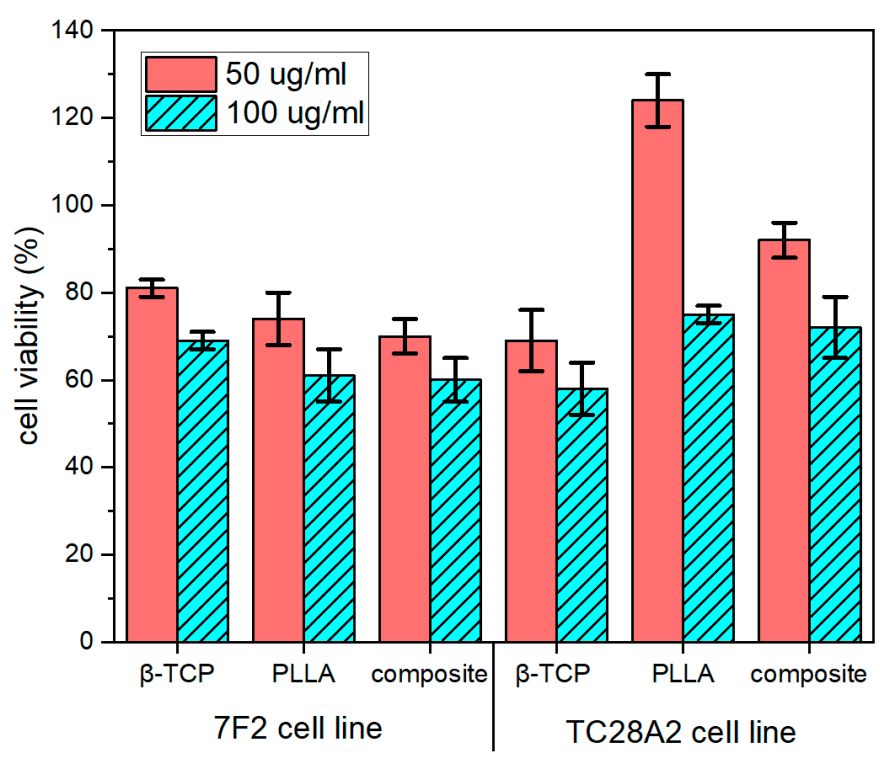

Figure 7. 7F2 and TC26A2 cells viability after $24 \mathrm{~h}$ of incubation and exposition on $\beta$-TCP co-doped with $\mathrm{Ce}^{3+}$ and $\mathrm{Pr}^{3+}$ ions, PLLA, and PLLA with $\beta$-TCP composite with phosphate:polymer 1:20 ratio, in concentrations of $50 \mu \mathrm{g} / \mathrm{mL}$ and $100 \mu \mathrm{g} / \mathrm{mL}$. 


\subsubsection{Hemolysis}

Tested compounds at concentrations of 50 and $100 \mu \mathrm{g} / \mathrm{mL}$ did not cause the hemolysis of ram erythrocytes. Obtained results were compared with the hemolysis caused by $1 \%$ of SDS solution (complete damage of the cellular membrane and hemoglobin release; data not shown) and are presented in Figure 8. Statistical analysis was also performed $(p<0.05)$ using one-way ANOVA test.

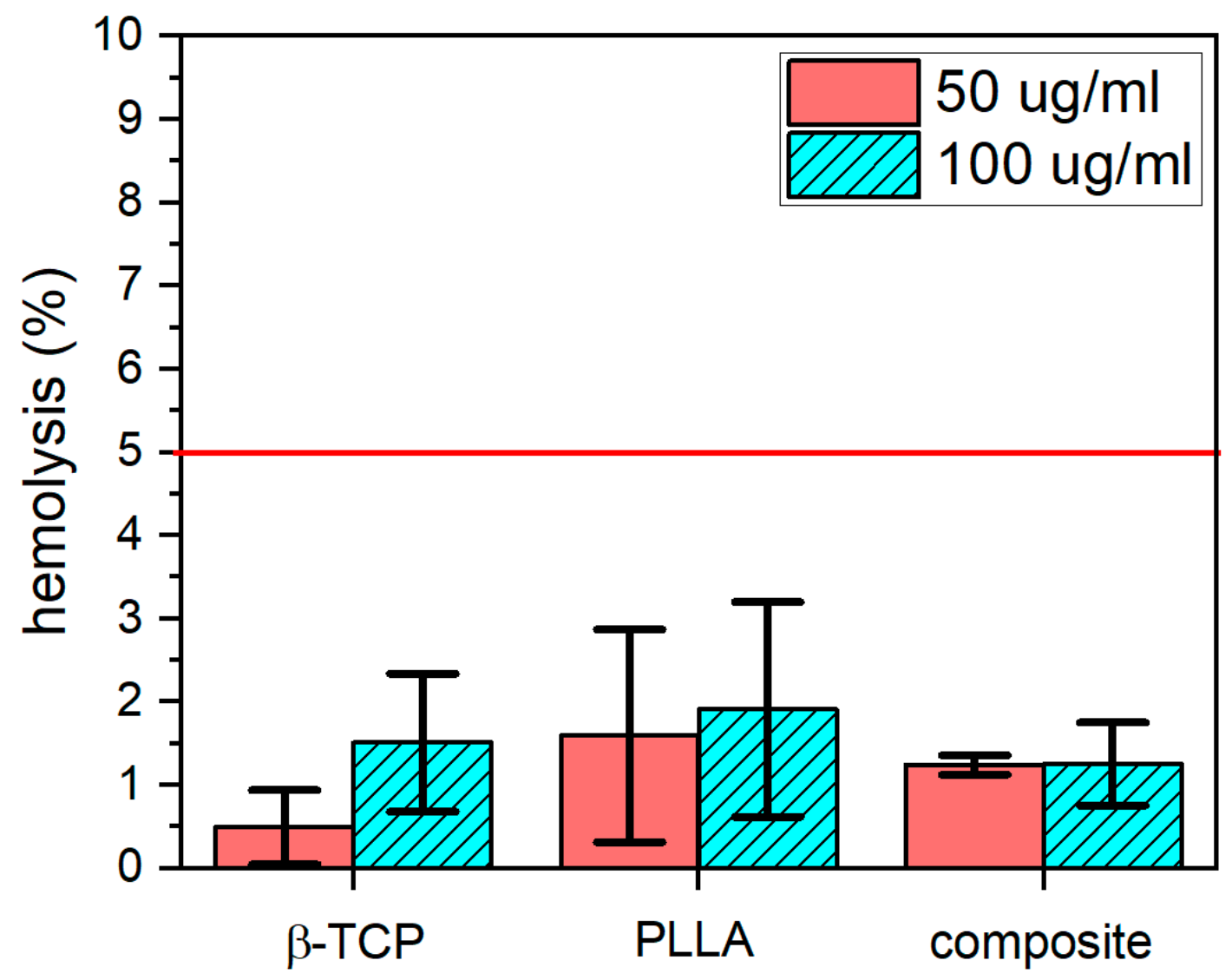

Figure 8. Activity of $\beta$-TCP co-doped with $\mathrm{Ce}^{3+}$ and $\mathrm{Pr}^{3+}$ ions, PLLA, and PLLA with $\beta$-TCP composite with phosphate:polymer 1:20 ratio, in concentrations $50 \mu \mathrm{g} / \mathrm{mL}$ and $100 \mu \mathrm{g} / \mathrm{mL}$ in reference to $1 \%$ of SDS solution (mean $\pm \mathrm{SD}, n=3$; all results were statistically significant). The red line indicates the acceptable hemolysis level.

Performing such an experiment is essential for chemical compounds designed to be applied in direct contact with the human body and its fluids. The acceptable range of hemolysis is set below $5 \%$ [33], therefore tested substances could be regarded as erythrocyte safe. Similar results were obtained by Zibiao et al. who proved that selected polymers based on PLLA and PEG did not cause an hemolysis higher than $5 \%$, even in higher concentrations [34]. The researchers proved that coating some commercial metal alloys with PEO/PLLA (plasma electrolytic oxidized/poly(L-lactide) composites can help reduce their hemolytic potential [35]. $\beta$-TCP was also tested before in order to check its hemolytic potential, but such effect was not observed [36].

\section{Conclusions}

In this work, the novel and self-assembled poly(L-lactide) (PLLA)/ $\beta$-tricalcium diphosphate $(\beta-\mathrm{TCP})$ composite has been prepared. In the first step, the well- $\beta$-TCP co-doped with $\mathrm{Ce}^{3+}$ and $\mathrm{Pr}^{3+}$ ions was obtained. Further, it was prepared precisely tailored to low-molecular mass PLLA on the $\beta$-TCP surface using biocatalysts from the group of zinc aminophenolates. The obtained materials may be potentially used to bone grafting and in vivo bioimaging in the near-infrared (NIR) 
window (also known as "optical window" or "therapeutic window"). PLLA has been used to enhance biocompatibility of the obtained composite for further application. Moreover, the polymer did not affect the luminescent properties of $\mathrm{Ce}^{3+}$ and $\mathrm{Pr}^{3+}$ ions co-doped $\beta$-TCP.

Furthermore, the hemolysis higher than $5 \%$ was not observed for all studied materials. It has been suggested that the obtained materials could be safely used in vivo because the cell proliferation and mitochondrial activity have not been disrupted. In conclusion, it might not interrupt the OXPHOS (Oxidative phosphorylation) and energy production in chondrocytes.

Author Contributions: R.J.W. conceived and designed the experiments as well as analyzed all data; J.A.Z., D.J., and J.E. contributed reagents/materials/analysis tools as well as analyzed data; A.W. and A.S. designed the experiments as well as analyzed luminescence data; N.N. and J.R.-S. contributed reagents/materials/analysis tools and analyzed biological data; all authors contributed to the writing of the paper. All authors have read and agreed to the published version of the manuscript.

Funding: Financial support of the National Science Centre in course of realization of the Projects "Preparation and characterization of biocomposites based on nanoapatites for theranostic (no. UMO-2015/19/B/ST5/01330) and "Biocompatible polyesters with accurately coded sequences: engineering, functionalization and applications" (no. UMO-2017/25/B/ST5/00597) and are gratefully acknowledge.

Acknowledgments: The authors would like to acknowledge Piotr Kuropka (Wrocław University of Environmental and Life Sciences) for the human chondrocyte cell line TC28A2 and Ewa Bukowskafor performing XRD measurements as well as Damian Szymański for SEM images (Institute of Low Temperature and Structure Research, Polish Academy of Sciences).

Conflicts of Interest: The authors declare no conflict of interest.

\section{References}

1. Zarrin, A.; Sadighian, S.; Rostamizadeh, K.; Firuzi, O.; Hamidi, M.; Mohammadi-Samani, S.; Miri, R. Design, preparation, and in vitro characterization of a trimodally-targeted nanomagnetic onco-theranostic system for cancer diagnosis and therapy. Int. J. Pharm. 2016, 500, 62-76. [CrossRef] [PubMed]

2. Wang, J.; Cui, H. Nanostructure-based theranostic systems. Theranostics 2016, 6, 1274-1276. [CrossRef]

3. Guyton, A.C.; Hall, J.E. Textbook of Medical Physiology, 11th ed.; Elsevier Saunders: Philadelphia, PA, USA, 2006; ISBN 0721602401.

4. Yashima, M.; Sakai, A.; Kamiyama, T.; Hoshikawa, A. Crystal structure analysis of $\beta$-tricalcium phosphate Ca3(PO4)2 by neutron powder diffraction. J. Solid State Chem. 2003, 175, 272-277. [CrossRef]

5. Wang, L.; Nancollas, G.H. Calcium Orthophosphates: Crystallization and Dissolution. Chem. Rev. 2008, 108, 4628-4669. [CrossRef] [PubMed]

6. Yang, H.; Kim, Y.-S. Energy transfer-based spectral properties of Tb-, Pr-, or Sm-codoped YAG:Ce nanocrystalline phosphors. J. Lumin. 2008, 128, 1570-1576. [CrossRef]

7. Murariu, M.; Doumbia, A.; Bonnaud, L.; Dechief, A.; Paint, Y.; Ferreira, M.; Campagne, C.; Devaux, E.; Dubois, P. High-Performance Polylactide/ZnO Nanocomposites Designed for Films and Fibers with Special End-Use Properties. Biomacromolecules 2011, 12, 1762-1771. [CrossRef] [PubMed]

8. Kim, H.; Park, H.; Lee, J.; Kim, T.H.; Lee, E.S.; Oh, K.T.; Lee, K.C.; Youn, Y.S. Highly porous large poly(lactic-co-glycolic acid) microspheres adsorbed with palmityl-acylated exendin-4 as a long-acting inhalation system for treating diabetes. Biomaterials 2011, 32, 1685-1693. [CrossRef]

9. Zhang, P.; Wu, H.; Wu, H.; Lù, Z.; Deng, C.; Hong, Z.; Jing, X.; Chen, X. RGD-Conjugated Copolymer Incorporated into Composite of Poly(lactide-co-glycotide) and Poly(l-lactide)-Grafted Nanohydroxyapatite for Bone Tissue Engineering. Biomacromolecules 2011, 12, 2667-2680. [CrossRef]

10. Bertrand, A.; Hillmyer, M.A. Nanoporous Poly(lactide) by Olefin Metathesis Degradation. J. Am. Chem. Soc. 2013, 135, 10918-10921. [CrossRef]

11. Dusselier, M.; van Wouwe, P.; Dewaele, A.; Jacobs, P.A.; Sels, B.F. Shape-selective zeolite catalysis for bioplastics production. Science 2015, 349, 78-80. [CrossRef]

12. Dechy-Cabaret, O.; Martin-Vaca, B.; Bourissou, D. Controlled Ring-Opening Polymerization of Lactide and Glycolide. Chem. Rev. 2004, 104, 6147-6176. [CrossRef] [PubMed]

13. Stanford, M.J.; Dove, A.P. Stereocontrolled ring-opening polymerisation of lactide. Chem. Soc. Rev. 2010, 39, 486-494. [CrossRef] [PubMed] 
14. Sarazin, Y.; Carpentier, J.F. Discrete Cationic Complexes for Ring-Opening Polymerization Catalysis of Cyclic Esters and Epoxides. Chem. Rev. 2015, 115, 3564-3614. [CrossRef] [PubMed]

15. Chisholm, M.H.; Eilerts, N.W. Single-site metal alkoxide catalysts for ring-opening polymerizations. Poly(dilactide) synthesis employing $\{\mathrm{HB}(3-\mathrm{ButPz}) 3\} \mathrm{Mg}(\mathrm{OEt})$. Chem. Commun. 1996, 853-854. [CrossRef]

16. Chamberlain, B.M.; Cheng, M.; Moore, D.R.; Ovitt, T.M.; Lobkovsky, E.B.; Coates, G.W. Polymerization of lactide with zinc and magnesium $\beta$-diiminate complexes: Stereocontrol and mechanism. J. Am. Chem. Soc. 2001, 123, 3229-3238. [CrossRef]

17. Chisholm, M.H.; Gallucci, J.C.; Phomphrai, K. Well-defined calcium initiators for lactide polymerization. Inorg. Chem. 2004, 43, 6717-6725. [CrossRef]

18. Wu, J.-C.; Huang, B.-H.; Hsueh, M.-L.; Lai, S.-L.; Lin, C.-C. Ring-opening polymerization of lactide initiated by magnesium and zinc alkoxides. Polymer 2005, 46, 9784-9792. [CrossRef]

19. Chuang, H.J.; Weng, S.F.; Chang, C.C.; Lin, C.C.; Chen, H.Y. Synthesis, characterization and catalytic activity of magnesium and zinc aminophenoxide complexes: Catalysts for ring-opening polymerization of l-lactide. Dalton Trans. 2011, 40, 9601-9607. [CrossRef]

20. Huang, M.; Pan, C.; Ma, H. Ring-opening polymerization of rac-lactide and $\alpha$-methyltrimethylene carbonate catalyzed by magnesium and zinc complexes derived from binaphthyl-based iminophenolate ligands. Dalton Trans. 2015, 44, 12420-12431. [CrossRef]

21. Williams, C.K.; Breyfogle, L.E.; Choi, S.K.; Nam, W.; Young, V.G.; Hillmyer, M.A.; Tolman, W.B. A Highly Active Zinc Catalyst for the Controlled Polymerization of Lactide. J. Am. Chem. Soc. 2003, 125, 11350-11359. [CrossRef]

22. Song, S.; Zhang, X.; Ma, H.; Yang, Y. Zinc complexes supported by claw-type aminophenolate ligands: Synthesis, characterization and catalysis in the ring-opening polymerization of rac-lactide. Dalton Trans. 2012, 41, 3266. [CrossRef]

23. Jedrzkiewicz, D.; Adamus, G.; Kwiecień, M.; John, Ł.; Ejfler, J. Lactide as the Playmaker of the ROP Game: Theoretical and Experimental Investigation of Ring-Opening Polymerization of Lactide Initiated by Aminonaphtholate Zinc Complexes. Inorg. Chem. 2017, 56, 1349-1365. [CrossRef]

24. Ejfler, J.; Kobyłka, M.; Jerzykiewicz, L.B.; Sobota, P. Highly efficient magnesium initiators for lactide polymerization. Dalton Trans. 2005, 2047-2050. [CrossRef]

25. Wojtaszak, J.; Mierzwicki, K.; Szafert, S.; Gulia, N.; Ejfler, J. Homoleptic aminophenolates of Zn, Mg and Ca. Synthesis, structure, DFT studies and polymerization activity in ROP of lactides. Dalton Trans. 2014, 43, 2424-2436. [CrossRef]

26. Jędrzkiewicz, D.; Czeluśniak, I.; Wierzejewska, M.; Szafert, S.; Ejfler, J. Well-controlled, zinc-catalyzed synthesis of low molecular weight oligolactides by ring opening reaction. J. Mol. Catal. A Chem. 2015, 396, 155-163. [CrossRef]

27. Guan, R.; Johnson, I.; Cui, T.; Zhao, T.; Zhao, Z.; Li, X.; Liu, H. Electrodeposition of hydroxyapatite coating on $\mathrm{Mg}-4.0 \mathrm{Zn}-1.0 \mathrm{Ca}-0.6 \mathrm{Zr}$ alloy and in vitro evaluation of degradation, hemolysis, and cytotoxicity. J. Biomed. Mater. Res. Part A 2012, 100, 999-1015. [CrossRef] [PubMed]

28. Shannon, R.D. Revised Effective Ionic Radii and Systematic Studies of Interatomie Distances in Halides and Chaleogenides. Acta Crystallogr. Sect. A Cryst. Phys. Diffr. Theor. Gen. Crystallogr. 1976, 32, 751-767. [CrossRef]

29. Tadrous, P.J.; Siegel, J.; French, P.M.W.; Shousha, S.; Lalani, E.-N.; Stamp, G.W.H. Fluorescence lifetime imaging of unstained tissues: Early results in human breast cancer. J. Pathol. 2003, 199, 309-317. [CrossRef] [PubMed]

30. Chen, H.-M.; Chiang, C.-P.; You, C.; Hsiao, T.-C.; Wang, C.-Y. Time-resolved autofluorescence spectroscopy for classifying normal and premalignant oral tissues. Lasers Surg. Med. 2005, 37, 37-45. [CrossRef]

31. Halestrap, A.P.; Wilson, M.C. The monocarboxylate transporter family-Role and regulation. IUBMB Life 2012, 64, 109-119. [CrossRef]

32. Esen, E.; Long, F. Aerobic Glycolysis in Osteoblasts Aerobic Glycolysis in Osteoblasts. Curr. Osteoporos. Rep. 2015, 12, 433-438. [CrossRef]

33. Aditya, N.P.; Chimote, G.; Gunalan, K.; Banerjee, R.; Patankar, S.; Madhusudhan, B. Experimental Parasitology Curcuminoids-loaded liposomes in combination with arteether protects against Plasmodium berghei infection in mice. Exp. Parasitol. 2012, 131, 292-299. [CrossRef] 
34. Li, Z.; Chee, P.L.; Owh, C.; Lakshminarayanan, R.; Loh, X.J. Safe and efficient membrane permeabilizing polymers based on PLLA for antibacterial applications. RSC Adv. 2016, 6, 28947-28955. [CrossRef]

35. Wei, Z.; Tian, P.; Liu, X.; Zhou, B. In vitro degradation, hemolysis, and cytocompatibility of PEO / PLLA composite coating on biodegradable AZ31 alloy. J. Biomed. Mater. Res. Part B: Appl. Biomater. 2015, 103, 342-354. [CrossRef] [PubMed]

36. Singh, R.K.; Kannan, S. Synthesis, Structural analysis, Mechanical, antibacterial and Hemolytic activity of $\mathrm{Mg} 2+$ and $\mathrm{Cu} 2+$ co-substitutions in $\beta-\mathrm{Ca} 3(\mathrm{PO} 4)_{2}$. Mater. Sci. Eng. C 2014, 45, 530-538. [CrossRef]

(C) 2020 by the authors. Licensee MDPI, Basel, Switzerland. This article is an open access article distributed under the terms and conditions of the Creative Commons Attribution (CC BY) license (http://creativecommons.org/licenses/by/4.0/). 